\title{
CHANGES IN SERUM PROTEINS ASSOCIATED WITH METAMORPHOSIS IN SALAMANDERS OF THE FAMILY AMBYSTOMATIDAE
}

\author{
Ronald A. NusSBaum \\ Museum of Zoology and Department of Zoology, University of Michigan, \\ Ann Arbor, MI 48104, U.S.A.
}

(Received 2 December 1974)

\begin{abstract}
The effect of metamorphosis on the serum proteins of three genera and five species of ambystomatid salamanders was examined by electrophoresis.

2. Four of the five species showed a significant increase in the fastest fraction upon metamorphosis.

3. Three of the five species showed a significant metamorphic increase in the second fastest fraction.

4. Four of the five exhibited a significant metamorphic increase in total protein.

5. The results support earlier hypotheses that a metamorphic increase in the fast components of amphibian blood serum serves to maintain blood volume in the desiccating, terrestrial environment of the transformed organism.
\end{abstract}

\section{INTRODUCTION}

ALMOST every homeostatic mechanism which has been adequately studied is seen to adjust during amphibian metamorphosis in such a manner as to enable the organsim to cope with the new physiological problems attendant with life on land. The morphological and physiological changes incurred at metamorphosis are accompanied with, and indeed most if not all are driven by, biochemical changes. In regard to biochemical changes, Wald $(1945,1952)$ and Crescitelli (1958) demonstrated metamorphic changes in visual pigments in frogs and salamanders; Munro (1953) and later authors found a switch from ammonotelism to ureotelism in amphibians, with correlative alterations in enzyme systems; and McCutcheon (1936) and Riggs (1951) described hemoglobin metamorphosis in frogs. These authors and others have argued convincingly for the specific adaptive nature of each of these biochemical changes. Wald $(1960,1961)$ has admirably summarized the literature.

Metamophosis of serum proteins in anurans was discovered by Frieden et al. (1957), and subsequent supportive results were summarized by Herner \& Frieden (1960) and Frieden (1961). Frieden and his associates found that concomitant with metamorphosis in Rana catesbeiana, $R$. hecksheri, $R$. grylio and Xenopus laevis there was: (1) a redistribution of the globulin fractions including either appearance of a fraction(s) for the first time, increase or decrease in quantity of certain fractions, or change in electrophoretic mobility; (2) no change in the mobility of albumin, the fastest fraction; (3) an increase in the total protein concentration; and (4) most notably, an increase in the amount of albumin relative to total globulin $(\mathrm{A} / \mathrm{G}$ ratio).

In 1956, Manelli found a metamorphic increase in the total serum protein concentration of the axolotl, Ambystoma mexicanum. As with frogs the fastest fraction, which Manelli (1958) equated with human albumin. increased the greatest amount at metamorphosis.
Manelli showed that neither sex nor maturity affected the metamorphic relationships of the proteins. Hahn (1962) demonstrated identical results for the tiger salamander, Ambystoma tigrinum, but suggested the fastest fraction was $\alpha$-globulin rather than albumin. Hahn thought that if the fraction was $\alpha$-globulin it served the same physiological function as the albumin of frogs, and he invoked the same explanation as to the adaptive significance of the metamorphic increase proposed by Frieden et al. (1957) for frogs.

It is well known that one important function of serum proteins is to maintain osmotic equilibrium between blood and tissue fluids (Bell et al., 1965). An increase in the total protein concentration at metamorphosis serves to increase the osmotic pressure of the blood and hence its water-retaining capacity, an important adaptive switch considering the transition from the aquatic environment of the larva to the drying, terrestrial habitat of the transformed frog or salamander. As pointed out by Frieden (1961) and others, albumin, with its lower molecular weight, exerts two to three times the osmotic pressure per unit weight than the globulins; and it is the albumin fraction (or at least the fastest fraction) which increases proportionately the greatest amount during metamorphosis. At the $\mathrm{pH}$ of blood, albumin is highly charged and therefore has a great ion-binding capacity. An increase in the ion-binding capacity per unit volume of blood at metamorphosis fulfills the greater transport needs associated with metabolism and excretion in the terrestrial environment (Frieden, 1961).

There is a phylogenetic counterpart to these ontogenetic changes. Permanently aquatic vertebrates such as fish have relatively low serum protein concentrations, especially in regard to the faster fractions, compared to fully terrestrial vertebrates (Prosser, 1950). The correlation between ontogeny and phylogeny for this and other biochemical changes associated with metamorphosis has been used to support 
arguments concerning the proposed adaptive significance of these changes (Wald, 1960).

The two species of Ambystoma sludied by Manelli (1958) and Hahn (1962) are the only salamanders andlyod to date. The purpose of this study was to examine the metamorphic pattern of serum proteins in three genera of ambystomatid salamanders representing a wide variety of ecological types with different life history patterns in order to test the generality of the metamorphic pattern, and to inquire further into the validity of the proposed adaptive value of the observed phenomena.

\section{MATERIALS AND METHODS}

Five species of ambystomatid salamanders from the Pacific Northwest were studied. Collecting sites were: Ambistoma macrodactylum, Summit Spring and Bear Spring, Cascade Mountains, Jefferson Co., Oregon; Ambystoma gracile, Willamette Valley. Polk and Benton Cos., Oregon; Dicamptodon ensatus, Cowlitz Co., Washington and Benewah and Valley Cos., Idaho; Dicamptodon 'opc'i. Cowlitz and Skamania Cos., Washington: Rhvacotritom olimpicus. Columbia River Gorge. Multnomah Co. Oregon. All specimens are deposited in the Museum of Zoology, University of Michigan.

Samples of larval and transformed A. gracile. A. macrodactylum, and $R$. olympicus were collected and tested with no previous treatment. Larval and transformed $D$. ensatus were also collected and tested with no treatment, but an additional sample of larvae was trated with thyroxine in order to observe the sequence of changes in serum protein patterns relative to the metamorphic process. This also allowed comparison between transformed animals from the field and those obtained by forced metamorphosis. D. copci apparently do not normally metamorphose (Nussbaum, 1970). A sample of larvae of this latter species was treated with thyroxine to force metamorphosis as far as possible. "Transformed" $D$. cope $i$ were used only after 12 continuous months of thyroxine treatment.

Blood was drawn from the heart of anesthetized animals into capillary tubes, allowed to clot, and the serum separated by centrifugation. Hemolytic samples were discarded. Samples were run within 1 hr of the time blood was drawn. Aliquots $(0.25 \mu \mathrm{l})$ were placed on biologically inert cellulose acetate membranes, and the proteins separated with a Beckman Microzone Cell, Model R-101. The proteins were allowed to migrate for $20 \mathrm{~min}$ at $250 \mathrm{~V}$, with a barbital buffer solution of $\mathrm{pH} 8.6$ and an ionic strength of 0.075 . Migration was stopped by placing the membrane in a fixitive dye $10.2 \%$ ponceau-S. $3.0 \%$ trichloroacetic acid, $3 \cdot 0 \%$ sulfosalicylic acid) for $8 \mathrm{~min}$. Excess dye was rinsed away with $5 \%$ acetic acid. The membranes were then dehydrated for $1 \mathrm{~min}$ in $95 \%$ ethanol, transferred to a clearing solution of $25 \%$ glacial acetic acid and $75 \%$ ethanol $(95 \%)$ for $1 \mathrm{~min}$. The dried membrane was placed in a clear envelope, and scanned with a Microzone densitometer. Beckman Model R-110. The densitometer is equipped with an automatic integrator, and the relative amounts of the protein fractions can easily be determined through its use. Migration rates were compared to human albumin.

Samples were grouped by species, sex, stage of sexual maturity, and locality. Thyroxine-treated $D$. ensatus were compared to those already metamorphosed when collected. Standard statistical tests were made which showed no effects of sex, thyroxine treatment, or state of maturity. so the samples were combined to compare only larval versus tranformed individuals within and between species. The two samples of $D$. e'nsatus from Idaho and Washington were different enough to warrant separate statistical treatment.

\section{RESL LT'S}

Five protein fractions were resolved, except that the sample of $D$. ensatus from Idaho had a sixth fraction labeled 3 in Fig. 4. The homologies of these proteins with those of higher vertebrates are not certain. They were therefore numbered in order, from the fistest to slowest fractions. Fraction 1 is comparable to human albumin in position: $R_{1}=0.93$ for Dicamplodon and Rhyacotriton, and $R_{i}=0.87$ for Ambistoma. Fraction 2 is in the same relative position as $x_{1}$-globulin. fraction 3 is comparable to $\psi_{2}$-globulin. fraction 4 to $\beta$-globulin. and 5 to $\%$-globulin.

The electrophoretic patterns for larval and transformed A. macrodactyhm are shown in Fig. 1 . It is evident that the relative amount of fraction $\mathrm{l} i \mathrm{in}$.
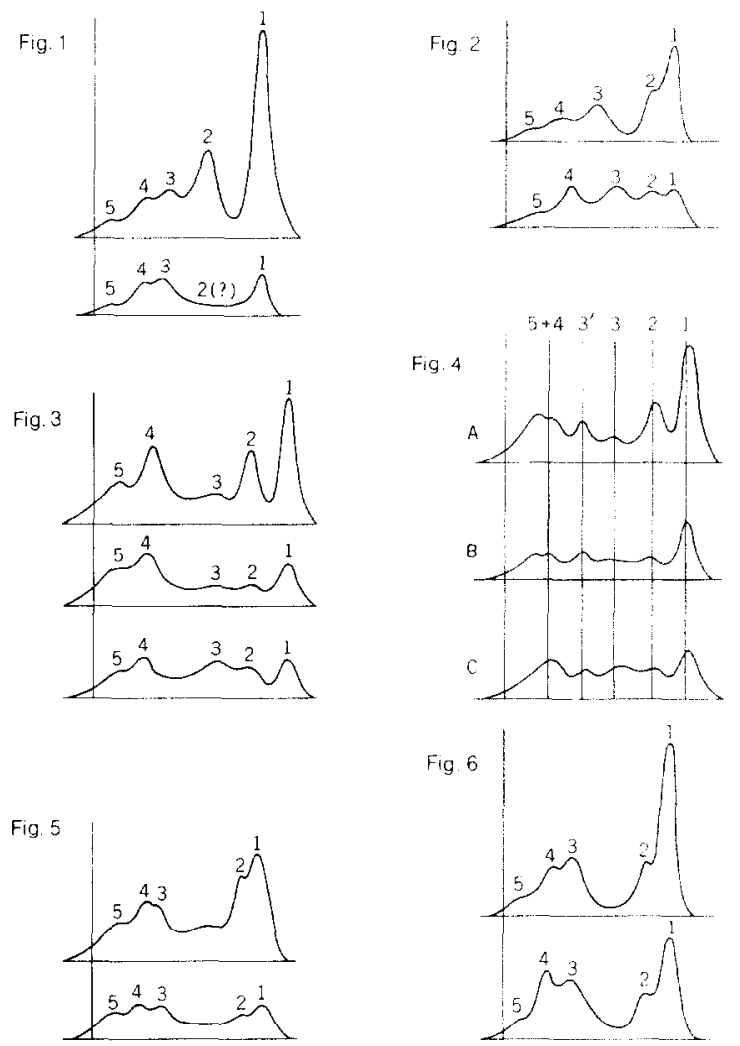

Fig. 1. Electrophorograms of larval (lower) and transformed (upper) Ambystoma macrodactilum. Vertical line marks point of application. Fractions 1 and 2 increase tremendously concurrent with metamorphosis.

Fig. 2. Electrophorograms of larval (lower) and transformed (upper) Ambistoma aracile.

Fig. 3. Electrophorograms of immature larva (lower), neotenic larva (middle), and immature but transformed (upper) Dicamptodon ensatus from Washington. This figure shows that the pattern of increase in fractions 1 and 2 is not dependent on sexual maturity.

Fig. 4. Electrophorograms of larval (lower) and transformed (upper) Dicamptodon ensatus from Idaho. The middle pattern is for an individual in the process of metamorphosing. Fraction $3^{\prime}$ is not found in D. ensatus from Washington (Fig. 3)

Fig. 5. Electrophorograms of larval (lower) and transformed (upper) Dicamptodon copei from Washington.

Fig. 6. Electrophorograms of larval (lower) and transformed (upper) Rhyacotriton olympictis. 
Table 1. Proportional changes in serum proteins associated with

metamorphosis. L = Larval; $\mathrm{r}=$ transformed; $\mathrm{W}=$ Washington

population; I = Idaho population; $A / G=$ albumin/total

globulin; $x^{\prime}-G^{\prime} G^{\prime}=$ alpha-globulin/total remaining globulin;

$A+\mathcal{X}-G^{\prime} G^{\prime}=$ albumin + alpha-globulin/remaining globulin.

Means and standard errors in parenthes is are given

\begin{tabular}{|c|c|c|c|c|c|}
\hline Species & $\mathrm{A} / \mathrm{G}$ & $x-G / G^{\prime}$ & $A+X-G / G^{\prime}$ & $\begin{array}{l}\text { Total } \\
\text { Protein }\end{array}$ & $\underline{n}$ \\
\hline A. macrodactylum (L) & $.576(.024)$ & $.000(-)$ & $.576(.024)$ & $61.0(2.47)$ & 16 \\
\hline A. macrodactylum (T) & $.883(.032)$ & $.216(.011)$ & $2.862(.115)$ & $220.0(9.22)$ & 12 \\
\hline A. gracile (L) & $.191(.020)$ & $.110(.011)$ & $.523(.043)$ & $126.7(10.20)$ & 10 \\
\hline A. gracile $(\mathrm{T})$ & $.505(.070)$ & $.142(.021)$ & $1.139(.072)$ & $96.9(9.51)$ & 8 \\
\hline D. ensatus (W, L) & $.264(.015)$ & $.169(.014)$ & $.551(.040)$ & $133.6(5.67)$ & 9 \\
\hline $\bar{D}$. ensatus $(W, T)$ & $.364(.011)$ & $.168(.014)$ & $.697(.033)$ & $150.3(10.37)$ & 8 \\
\hline D. ensatus $(I, L)$ & $.271(.026)$ & $.178(.009)$ & $.575(.046)$ & $116.2(5.65)$ & 5 \\
\hline D. $\overline{\text { ensatus }}(I, T)$ & $.462(.025)$ & $.226(.004)$ & $1.003(.045)$ & $162.2(10.88)$ & 6 \\
\hline D. copei (L) & $.339(.021)$ & $.095(.005)$ & $.683(.041)$ & $100.2(5.20)$ & 11 \\
\hline D. copei (T) & $.397(.022)$ & $.204(.017)$ & $1.388(.153)$ & $145.8(7.61)$ & 6 \\
\hline R. olympicus (L) & $.428(.016)$ & $.103(.006)$ & $.850(.047)$ & $254.8(7.30)$ & 8 \\
\hline R. olympicus (T) & $.621(.025)$ & $.108(.007)$ & $1.181(.049)$ & $187.1(7.32)$ & 17 \\
\hline
\end{tabular}

creases significantly at metamorphosis. Thus the $A / G$ (albumin/globulin) ratio increases from 0.576 to 0.883 (Table 1). Just as striking is the metamorphic change in fraction 2. This protein was not detectable in larvae, but amounts to $21.6 \%$ of the globulin component of transformed individuals. The total protein concentration was 3.61 times higher in transformed, as compared to larval individuals.

There was also a significant metamorphic increase in fraction 1 for $A$. gracile, but fraction 2 did not increase significantly (Fig. 2, Table 1). Fraction 2 is present in larval $A$. gracile, whereas it was not in A. macrodactylum. There was a decrease in total protein concomitant with metamorphosis (Table 1). Compared to other data for frogs (Frieden, 1961) and salamanders (Manelli, 1958; Hahn, 1962; this paper) this result seems anomalous, and cannot be explained completely. Samples of serum of transformed $A$. gracile were less viscous than any other samples. Since the applicator works on the principle of surface tension, a less viscous serum would tend to be applied to the membrane in smaller quantities, and this sampling error could in part account for the anomaly.

D. ensatus from Washington (Fig. 3) showed a significant, metamorphic increase in the relative amount of fraction 1, but not of fraction 2 (Table 1). A subsample of five, large, neotenic larvae from Washington showed results indistinguishable from those of smaller, immature larvae. D. ensatus from Idaho (Fig. 4) had an even greater increase in the $A / G$ ratio associated with metamorphosis, and there was a significant increase in fraction $2\left(x-G / G^{\prime}\right)$. D. ensatus from Idaho showed a significant increase in total protein, but those from Washington did not.

The metamorphic increase in the ratio $A / G$ for $D$. copei (Fig. 5) is not significant at $P<0 \cdot 05$. This is the only species examined for which this is true. As noted above, this species does not normally transform. Morphological changes do not go to completion by administration of thyroxine (Nussbaum, 1970), and perhaps the present result indicates a similarly incomplete biochemical metamorphosis. There is a significant increase in the relative amount of fraction 2 after thyroxine treatment, as well as a significant increase in total protein (Fig. 5, Table 1).

There is a significant increase in the relative amount of fraction 1 upon transformation of $R$. olympicus (Fig. 6, Table 1), but not of fraction 2. There is likewise a significant increase in total protein.

\section{DISCUSSION}

The proposal by Frieden et al. (1957) that the increase in albumin attendant with metamorphosis is designed by natural selection to meet the osmotic needs of the organism in the terrestrial environment, is by no means proven. The hypothesis is logical and attractive, but so far is supported only by the fact that there is an increase in the fast fraction of a few species of frogs and salamanders associated with transformation. It is proposed now to examine the evidence more closely with special attention given to the live histories and habitats of the species involved.

It was shown above that in some species of sala manders there is a metamorphic increase in the relative amount of fraction 2 as well as fraction 1. No reason can be thought of why this second fastest fraction should not be given the same consideration as potentially important in osmotic control, and consideration will be given to both fractions from this point-of-view.

Since the metamorphic change is not all-or-none, it is possible to search for patterns, across and within species, in the degree of change in relation to the degree of independence of water of the terrestrial stage. Hence if the theory is correct, the most terrestrial species should show the greatest metamorphic increase in fractions 1,2 or both. Similar arguments can be advanced for populations within species.

A. macrodactylum is the most widespread geographically, and occupies a greater diversity of habitats than any of the species studied. It breeds in forested, montane situations as well as in the xeric, sagebrush plains of the Columbia Plateau. Neotenic 
populations are unknown. Of the six species studied, the terrestrial adults of $A$. macrodactylum are the most independent of water, except of course during the breeding season. Fractions 1 and 2 have been combined in relation to the remaining globulins $(\mathrm{A}+$ $\left.\alpha \mathrm{G} / \mathrm{G}^{\prime}\right)$ for comparison of the metamorphic pattern across species. During metamorphosis of A. macrodactylum this ratio changes from 0.576 to 2.862 , an increase of 4.97 times.

A. gracile is restricted in distribution to the humid, Coastal and Cascade forests of the Pacific Coast of western North America. Permanently aquatic, neotenic populations are known. Terrestrial individuals are usually found near permanent water. The distribution, life history, and habitat of terrestrial individuals suggest this species has a greater moisture dependency than $A$. macrodactylum. The ratio $\mathrm{A}+x \mathrm{G} / \mathrm{G}^{\prime}$ for $A$. gracile increases metamorphically from 0.523 to 1.139 or 2.18 times.

$D$. ensatus is similar to $A$. gracile in that both species are restricted primarily to moist, montane or coastal regions. D. ensatus from coastal California, Oregon and Washington are similar to sympatric $A$. gracile in that both species have neotenic or partially neotenic populations. However, $D$. ensatus from the inland, more xeric forests of the Rocky Mountains of Idaho are not known to have neotenic populations (Nussbaum, unpubl.); and terrestrial individuals often occur in relatively dry circumstances compared to the coastal situation. As can be seen from Table 1, D. ensatus from Idaho show a greater metamorphic response in the ratio $\mathrm{A}+\alpha \mathrm{G} / \mathrm{G}^{\prime}$ than do those from Washington (1.74 as opposed to 1.26). Since $D$. copei do not normally metamorphose, they will not be considered in this part of the discussion.

$R$. olympicus is restricted to the humid, coastal forests of the Pacific Northwest. Transformed individuals afe seldom found more than a meter from a permanent seep or stream, and usually they are found in the splash or spray zone, their bodies in contact with the water film. There are no neotenes. In this salamander the ratio $\mathrm{A}+\alpha \mathrm{G} / \mathrm{G}^{\prime}$ increases from 0.850 to 1.181 during metamorphosis for an increase of 1.39 times.

It was contended that $A$. macrodactylum and $R$. olympicus occupy opposite ends of a dry-wet, ecological spectrum. Terrestrial individuals of both species can be found on saturated substrate, especially during the breeding season or after rains. However, the critical factor is the extremes of drought to which individuals may be exposed. Outside the breeding season, A. macrodactylum are often found on relatively dry substrate, whereas $R$. olympicus are always collected in saturated microhabitats. These field observations are supported by laboratory studies. Ray (1958) compared the dehydration-hydration rate of $R$. olympicus to more terrestrial plethodontid salamanders and found that $R$. olympicus: (1) exhibits great irritation on contact with dry air; (2) lacks any protective behavioral mechanism to prevent desiccation (such as reducing body surface area by coiling); and (3) has a relatively fast dehydration rate. $R$. olympicus also has a relatively low tolerance of water loss (unpubl. data supplied by Dr. Stanley Anderson, Kenyon College). Alvarado (1967) noticed that both $A$. macrodactylum and $A$. tigrinum tended to form clumps if exposed to dehydrating conditions in the laboratory. His experiments showed that individuals in clumps dehydrated much more slowly than single individuals. and he hypothesized that aggregative behavior would have survival value in desiccating environments. Field observations taken support Alvarado's ideas in that several aestival aggregations of $A$. macrodactylum of up to 33 individuals were found. This discussion has been belabored because acceptance of these arguments in conjunction with the relatively greater metamorphic increase in $\mathrm{A}+x \mathrm{G} / \mathrm{G}^{\prime}$ for A. macrodact vlum (4.97 times) compared to $R$. olympicus (1.39 times) greatly strengthens the hypothesis of Frieden al al. (1957) concerning the adaptive significance of this phenomenon.

Bertini \& Cei (1960) reported that transformed toads, Bufo arenarum, from two arid localities in South America had significantly higher amounts of serum albumin than did individuals from three separate humid localities. They suggested the higher albumin concentration was an adaptation for resistance to ambient aridity, but gave no reason for this assertion and did not seem to be aware of Frieden's hypothesis. They also showed a geographic increasc in the second fastest protein (their $\mathrm{G}^{\prime}$ ) corresponding to the more arid localities, but did not discuss this result.

In summary, there is both interspecific (A. macrodactylum and $R$. olympicus) and intraspecific $(D$. ensatus and $B$. arenarum) evidence that higher concentrations of albumin (or at least the fast fraction) are characteristic of transformed individuals of populations adapted to more xeric conditions. There arc several groups of amphibians perfect for further testing this generality, the best of which is perhaps the desmognathine salamanders which form a linear series from aquatic- to terrestrial-adapted species (Hairston, 1949, 1973).

Another approach is to examine species which metamorphose but nevertheless remain aquatic. If resistance to desiccation is the main adaptive advantage to increased albumin or $x$-globulin then ther: should be no reason for these fractions to increase if transformation is not accompanied with transition to land. Rall et al. (1961) demonstrated that a new, fast component appeared in the serum proteins of the sea lamprey, Petromyzon marinus upon transformation. The authors thought the new component was -globulin, but did not speculate on the functional significance of their finding. Since lampreys are aquatic throughout their life cycle, it would seem that the metamorphic appearance (increase?) of a fast fraction must serve some function other than to maintain blood bolume in desiccating environments. In the case of $P$. marimus, however, it could be argued that since the larvae live in fresh water and the adults are historically inhabitants of the sea (freshwaler. landlocked populations are known), then the increased concentration of the fast fraction may serve the same function; i.e. prevention of dehydration (maintenance of blood volume), but in this case imposed by a hypertonic, aquatic environment rather than a drying atmosphere.

Herner \& Frieden (1960) studied the metamorphic pattern of the pipid frog. Xenopus laevis, a species well known by experimental biologists to remain 
aquatic throughout the life cycle. Yet $X$. laevis exhibits a marked increase in the $A / G$ ratio upon metamorphosis. The authors showed that the pattern for $X$. laevis differed from Rana in that both the $A / G$ ratio and total protein concentration increased steadily as the transformed froglet grew; whereas the metamorphic change in the more terrestrial Rana was more abrupt and changed little after metamorphosis. These observations are consistent with the hypothesis in that Rana froglets are immediately confronted with a dehydrating environment whereas $X$. laevis froglets are not. The fact that there is a gradual increase in the $A / G$ ratio of $X$. laevis is not inconsistent if one considers this frog in its natural habitat. $X$. laevis occurs in the temporary pond or "vlei" habitats of South Africa. Here the species is often confronted with desiccation during droughts when their pools dry up. The tadpoles always succumb when this happens, but the transformed frogs often survive until the next rain by aestivating in the soil of the dried pond bottom (Rose, 1929).

The salamander Cryptobranchus alleghaniensis transforms from larvae to permanently aquatic adults, apparently with no concomitant change in the serum proteins (Stone, 1971; cited by Nickerson \& Mays, 1973).

The metamorphic increase in $A / G, \alpha-G / G^{\prime}$, and total serum protein in amphibians and other vertebrates likely has multiple functions. Previous evidence and data presented here suggest that a major function is related to water conservation and maintenance of blood volume in desiccating environments. The relative importance of this particular function could be measured with a species such as the newt, Notophthalmus viridescens which undergoes a "secondary metamorphosis" and returns to a permanently aquatic existence. The terrestrial eft stage should have higher $A / G$ and total protein values than both the aquatic larvae and the aquatic adults. The differences between the larvae and aquatic adults, if there are differences, should reflect adaptive changes unrelated to osmoregulatory problems imposed by the environment.

Whipple (1956) suggested that biosynthesis of albumin may be regulated in a homeostatic manner by the osmotic needs of the animal. This then should be measurable in some species of newts of the genera Taricha and Triturus in which after metamorphosis and growth, individuals alternate between periods of "aquatic" and "terrestrial" morphology in relation to the breeding cycle.

Acknowledgements-The author wishes to thank Dr. Edmund D. Brodie, Jr. and Ms. Jenny Hackforth-Jones for helpful comments, and Dr. Philip C. Dumas for the loan of electrophoretic equipment.

\section{REFERENCES}

Alvarado R. H. (1967) The significance of grouping on water conservation in Ambystoma. Copeia 1967(3), 667 668 .
Bell G. H., Davidson J. N. \& Scarborough H. (1965) Textbook of Physiology and Biochemistry i-vii $+1140 \mathrm{pp}$. Williams \& Wilkins. Baltimore.

Bertini F. \& CEI J. M. (1960) Observaciones electroforeticas en seroproteinas de poblaciones Argentinas de Bufo arenarum. Rev. Soc. argent. Biol. 36, 355-362.

Crescitelli F. (1958) The natural history of visual pigments. Ann. N.Y. Acad. Sci. 74. 230.

FriEDEN E. (1961) Biochemical adaptation and anuran metamorphosis. Am. Zoologist 1. 115-149.

Frieden E., Herner A. E., Fish L. \& Lewis E. J. C. (1957) Changes in serum proteins in amphibian metamorphosis. Science, N.Y. 126, 559-560.

HAHN W. E. (1962) Serum protein and erythrocyte changes during metamorphosis in paedogenic Ambystoma tigrinum mavortium. Comp. Biochem. Physiol. 7, 55-61.

Hatrston N. G. (1949) The local distribution and ecology of the plethodontid salamanders of the Southern Appalachians. Ecol. Monogr. 19, 47-73.

HaIRSTON N. G. (1973) Ecology, selection, and systematics. Breviora 414. 1-21.

Herner A. E. \& Frieden E. (1960) Biochemistry of anuran metamorphosis. VII. changes in serum proteins during spontaneous and induced metamorphosis $J$. biol. Chem. 235(10), 2845-2851.

MANELl H. (1958) Changes of the electrophoretic serum pattern of Amblystoma according to age, sex, and metamorphosis. Riv. Biol. 50. 15-26. (Italian)

MCCUTCHEON F. H. (1936) Hemoglobin function during the life history of the bullfrog. J. cell. comp. Physiol. 8. $63-81$.

Munro A. F. (1953) The ammonia and urea excretion of different species of amphibians during their development and metamorphosis. Biochem. J. 54. 29-36.

Nickerson M. A. \& MAYs C. E. (1973) The hellbenders. Milwaukee Public Museum, Publ. Biol. Geol. 1, 1-106.

Nussbaum R. A. (1970) Dicamptodon copei, n. sp., from the Pacific Northwest, U.S.A. (Amphibia: Caudata: Ambystomatidae). Copeia 1970. 506-514.

Prosser C. L. (Ed.). (1950) Comparative Animal Physiology. W. B. Saunders. Philadelphia.

Rall D. P., Schwab R. \& Zubroad C. G. (1961) Alteration of plasma proteins at metamorphosis in the lamprey (Petromyzon marinus dosatus). Science, N.Y. 133. $279-280$.

RAY C. (1958) Vital limits and rates of desiccation in salamanders. Ecology 39(1), 75-83.

RigGs A. F. (1951) The metamorphosis of hemoglobin in the bullfrog. J. gen. Physiol. 35. 23-40.

Rose W. (1929) Veld and Vlei i-xxiii +240 pp. Specialty Press of South Africa, Capetown.

WALD G. (1945) The chemical evolution of vision. Harvey Lectures 41. 117.

WALD G. (1952) Biochemical evolution. In Modern Trends in Physiology and Biochemistry (Edited by BARRoN E. S. G.). Academic Press, New York.

WALD G. (1960) The significance of vertebrate metamorphosis. Circulation 21, 916.

WALD G. (1961) Phylogeny and ontogeny at the molecular level. Evolutionary Biochemistry (Edited by OParin, A.), Proc. Fifth International Congress of Biochemistry, Vol. 3.

WhiPple C. H. (1956) The Dynamic Equilibrium of Body Proteins. Charles G. Thomas, Springfield, Illinois. 